\title{
Regional model for the protection of human rights in Asia
}

\author{
Dr. Sanjay Kumar Yadav \\ Associate Professor \\ National Law Institute University, Bhopal \\ Kerwa Dam Road, Bhopal, M.P., India \\ E-mail address: sanjay_nliu@rediffmail.com
}

Keywords: Human Rights, Convention, Regional, Duties, Commission, Asia, human rights court.

\begin{abstract}
After considering all the regional model for the protection of human rights in the world, the researcher tried to gave the regional model in Asia. There is need to care of diversified socio, economic, political and cultures of India while forming regional model for protection of human rights in Asia.
\end{abstract}

\section{INTRODUCTION}

In Asia there is no regional institution for the protection of human rights. European Convention of Human Rights, 1950 is the regional convention which was born in order to overcome the weaknesses of UNO. All the other regional model which was adopted afterward followed the European model according to the social, political, economical and cultural conditions of the region. In 1965, the Bangkok Congress of South East Asia and Pacific jurists discussed for the drafting of an Asian Convention on Human Rights. Again a proposal for similar Convention was made by the International Commission of jurists in the conference held in Ceylon in January 1966. The ministers and representatives of Asian States, meeting at Bangkok from 29 March to 2 April 1993, pursuant to General Assembly resolution 46/116 of 17 December, 1991 in the context of preparations for the World conference on Human Rights Adopts this declaration to be known as "The Bangkok Declaration", which contains the aspirations and commitments of the Asian region. In Bangkok Asian Inter-governmental meeting stress was made on cooperation at national, regional and international levels for the effective protection of human rights. But no success could be achieved, the factors which impeded the creation of an regional Convention or a Commission are diversity in religious faith, languages, custom and traditions. Further the continent has been the battle ground on many occasions. The notable point in the conflicts is that these States were backed by the big powers. The States in Asia are the victims of their rivalry.

After analyzing the existing regional machinery for the protection of human rights like European Convention, Inter-American Convention, African Convention of human rights, the researcher tried to present the regional model for the protection of human rights in Asia.

Regional institution for the protection of human rights in Asia can be formed on the example of existing regional institution, because these model are very successful in the protection of human rights and try to cover all the weakness of UNO. But one cannot ignore the conditions, which are peculiar in Asia, and one cannot copy any particular model because each regional convention is made according to their own conditions. So the existing regional conventions should be used as guiding principles only.

In Asia there are diversity in religious faith, languages, customs and tradition. Some part is developed and some are still in developing stage or underdeveloped. Therefore there is need to adopt mixed features of the existing regional institution for the protection of human rights. First there is need to form Asian Council, in order to bring all the countries of Asia on a common platform. Which latter on prepare draft of Asian Convention of human rights. It would come into force after the ratification of at least $2 / 3$ member States and try to persuade other member States to become part of it. 


\section{ASIAN CONVENTION OF HUMAN RIGHTS}

\section{Part-I}

\section{Human Rights guaranteed by the Convention}

1. Civil and political rights- first generation of human rights.

2. Social, cultural and economic rights- second generation of human rights.

3. Third generation of human rights or rights of people rather than individual e.g. right to development, right to self determination, right to peace, special protection to suppressed class etc.

Author advocates that there should be step by step approach should be adopted in achieving the rights guaranteed by the convention. In Asia some countries are developed, some are developing and some are under developed therefore first member nations accordingly tried to provide first generation of human rights and latter on as they developed then they try to provide the second and third generations of human rights.

\section{Part II}

\section{Duties of the individual}

1. Duties towards other human beings;

2. Duties towards family;

3. Duties towards society;

4. Duties towards nation.

Rights guaranteed under the convention may be suspended during emergency. But certain category of inalienable human rights can not taken away even during like right to life, immunity from torture or inhuman treatment, slavery and servitude, protection from unlawful detention, fair trial etc.

\section{Organs:}

\section{(A) Human Rights Commission}

\section{Member}

Human Rights Commission would comprised of one member from each of the signatories State. Members must be of high moral character and member of highest judiciary of his/her State.

\section{Functions}

1.To receive the complaints of violation of human rights from member States and individual.

2.In case prima facie established that there is a violation of human rights, send the case to the human rights court after collecting necessary facts and reports on it.

3.To grant interim relief if necessary in particular case of violation of human rights.

4.To take necessary steps for the protection of human rights, whenever there is a grave violation of human rights by the States, without waiting for any complaint on it.

\section{(B) Human Rights Court \\ Member \\ Members equal to the number of signatories to the convention. Member must be of high moral character and hold position as a judge in superior judiciary of that State.}

\section{Functions}

To decide the case send by the Commission. Decide the case by majority and send the judgment to the committee of ministers for enforcement. They also perform advisory function also related to the interpretation of the Convention. The jurisdiction of the court extended to all cases concerning the application and interpretation of the Convention. 


\section{(C) Committee of ministers}

It consists of foreign ministers of all the signatories of the member States. Its function is to monitor the enforcement of the decision of Human Rights Court and to take necessary action in case of non enforcement of the decision of Human Rights Court.

\section{(D) Human Rights promoting cell}

It consists of NGO's of member States and their function is to take necessary steps in creating awareness among peoples about human rights and how they protect their human rights in case of violation of it.

\section{Implementation of the Convention}

Following measures would be adopted for the implementation of Convention:

(a) Reporting procedure: Members States should send report annually to the Human Rights Commission about steps taken for the protection and promotion of human rights in their State.

(b)Inter-State communication: One State may send complaint against the other State for the violation of human rights in their State by other State or in case there is a violation of human rights observed by a State in the State of any member State to the Human Rights Commission, provided that both the States are signatories of the Convention.

(c) Individual communication: Any individual for the violation of human rights by another individual or State, may send his/her complaint to the Commission provided that;

(i) there is no remedy available in domestic law;

(ii) all domestic remedies are exhausted;

(iii) petition is not pending in any other regional or international forum;

(iv) there is no unreasonable delay in disposal of his petition at domestic forum.

In case of grave violation of human rights by the State like genocide, forced disappearance, etc. individual can directly approach to the Commission without exhaustion of domestic remedies.

(d) Representative standing: Due to illiteracy and lack of awareness in Asian region, there is need to allow representative standing on behalf of poor and needy people by NGO's or any other people on behalf of them in the Commission.

(e) Judgment of the court must be binding: For the effective protection of human rights there is need to make the judgment of the Human Rights Court binding on the individual and member States, and must not be of recommendatory nature.

\section{References:}

[1]. In this paper projective approach has been adopted by the author toward the title of paper and after studying all the regional institutions for the protection of human rights tried to give regional model for the protection of human rights in Asia and this paper is also based on the unpublished part of his LL.M., dissertation.

[2]. European Convention on Human Rights 1950

[3]. Inter-American Convention on Human Rights 1969

[4]. African Charter on Human Rights 1981 